\title{
PARADA CARDIORESPIRATÓRIA E REANIMAÇÃO CARDIOPULMONAR: ESTRATÉGIAS UTILIZADAS PARA EDUCAÇÃO PERMANENTE NA ENFERMAGEM
}

\section{ARTIGO DE REVISÃO}

COSME, André Lucas da Silva ${ }^{1}$, SILVA, Claudia Maria Santos Leite da², FERREIRA, Silvana Margarida Benevides ${ }^{3}$, SANTANA, Adrianne Ferreira de ${ }^{4}$

COSME, André Lucas da Silva. Et al. Parada cardiorespiratória e reanimação cardiopulmonar: estratégias utilizadas para educação permanente na enfermagem. Revista Científica Multidisciplinar Núcleo do Conhecimento. Ano 06, Ed. 06, Vol. 05, pp. 133-143. Junho de 2021. ISSN: 2448-0959, Link de acesso: https://www.nucleodoconhecimento.com.br/saude/reanimacao-cardiopulmonar, DOI: 10.32749/nucleodoconhecimento.com.br/saude/reanimacao-cardiopulmonar

\section{RESUMO}

A Parada Cardiorrespiratória constitui-se como uma das principais emergências médicas no mundo, em decorrência do seu alto potencial de mortalidade. Nesse sentido faz-se necessário que sejam desenvolvidas atividades de Educação Permanente em Saúde, para manter os profissionais atualizados e consequentemente garantir a qualidade da assistência prestada ao paciente em PCR. O objetivo foi identificar as estratégias utilizadas para Educação Permanente

\footnotetext{
${ }^{1}$ Graduado em Enfermagem pela Universidade de Cuiabá e Especialista em Saúde do Adulto e Idoso com ênfase em cardiovascular pela Universidade Federal de Mato Grosso.

${ }^{2}$ Graduado em Enfermagem pela Universidade do Estado de Mato Grosso e Especialista em Saúde do Adulto e idoso com ênfase em cardiovascular pela Universidade Federal de Mato Grosso.

${ }^{3}$ Enfermagem e Obstetrícia pela Universidade Federal de Mato Grosso (FAEN/UFMT), Especialização em Pediatria e Gerenciamento de Serviços de Saúde (FAEN/UFMT), Mestrado em Saúde e Ambiente (Instituto de Saúde Coletiva/UFMT), Doutorado em Ciências da Saúde/Universidade Federal de São Paulo (UNIFESP) e PósDoutorado pela Escola de Enfermagem da Universidade de São Paulo (EEUSP).

${ }^{4}$ Enfermagem e Obstetrícia pela Escola de Enfermagem de Ribeirão Preto da Universidade de São Paulo -USP. Especialista em Enfermagem em Infectologia pela Escola de Enfermagem de Ribeirão Preto da Universidade de São Paulo -USP. Mestre em Enfermagem Fundamental pela Escola de Enfermagem de Ribeirão Preto da Universidade de São Paulo -USP.
}

RC: 88139

Disponível em: https://www.nucleodoconhecimento.com.br/saude/reanimacaocardiopulmonar 
em Saúde entre Enfermeiros frente ao Suporte Básico de Vida e Suporte Avançado de Vida em adultos. Trata-se de uma revisão da literatura de abordagem qualitativa. As buscas foram realizadas nas bases PUBMED, LILACS e BVS, com textos em inglês, português e espanhol. Foram identificados 12 artigos, sendo 4 duplicados e 2 não disponíveis na íntegra. A maior parte dos estudos foram realizados no Brasil, com maior prevalência nos anos de 2016 e 2019. As estratégias que mais ganharam destaque nos estudos foram: o treinamento teórico atrelado a prática de simulação clínica; e cursos online / Ambiente Virtual de Aprendizagem. Foi possível evidenciar uma predominância de duas estratégias para o desenvolvimento da Educação Permanente em Saúde para a Enfermagem no que diz respeito a Parada Cardiorrespiratória em adultos. São necessários novos estudos para aprimorar as estratégias existentes e possibilitar o desenvolvimento de novas estratégias.

Palavras-chave: Reanimação Cardiopulmonar, Parada Cardíaca, Educação Continuada em Enfermagem.

\section{INTRODUÇÃO}

A Parada Cardiorrespiratória (PCR) constitui-se como uma das principais emergências médicas no mundo, em decorrência do seu alto potencial de mortalidade e da rapidez com que pode levar a morte (SBC, 2019). A PCR é a cessação súbita, inesperada, da circulação sistêmica, atividade ventricular útil e ventilatória de um indivíduo. É considerada uma das maiores emergências na qual um profissional de saúde pode se deparar ao longo de sua atuação, demandando uma conduta rápida e eficaz para reversão do quadro do paciente (AHA, 2015; DIAZ et al, 2017).

Uma pessoa em parada cardíaca fora do ambiente hospitalar nem sempre recebe ressuscitação cardiopulmonar $(\mathrm{RCP})$, provavelmente devido à falta de conhecimento das pessoas que testemunharam a emergência (GARCÍA; PEDROVIEJO; GÓMEZ, 2019). Tendo isso em vista, é necessário preparar a população e principalmente os acadêmicos e profissionais da saúde, para uma possível situação de PCR, para um 
atendimento imediato e busca de ajuda adequada. Deste modo, o conhecimento pode auxiliar na fortificação de uma rede de suporte para indivíduos em PCR, tendo como a sua principal consequência, uma maior chance na sobrevida do indivíduo.

As diretrizes de Suporte Básico de Vida e Suporte Avançado de Vida (SAV) são atualizadas periodicamente, no caso do Brasil são seguidas as diretrizes da American Heart Association, que atualiza as suas diretrizes em média a cada 5 anos, e recentemente suas orientações vêm sendo atualizadas com maior frequência (AHA, 2020).

A RCP é uma habilidade utilizada com baixa frequência em muitos locais de prática, os enfermeiros são frequentemente os primeiros profissionais a atender as paradas cardíacas em clínicas, hospitais e outros ambientes. Sendo assim, necessitam de treinamento inicial de RCP eficaz e atualizações (KARDONG et. al., 2010).

Deste modo, faz-se necessário que sejam desenvolvidas atividades de Educação Permanente em Saúde, para manter os profissionais atualizados e consequentemente garantir a qualidade da assistência prestada ao paciente em PCR. Nesse sentido, o objetivo do estudo é identificar as estratégias utilizadas para Educação Permanente em Saúde entre Enfermeiros frente ao Suporte Básico de Vida e Suporte Avançado de Vida em adultos. Configurou-se, desta forma, a seguinte questão norteadora de pesquisa: Quais as evidências cientificas disponíveis na literatura que relatam as estratégias utilizadas por instituições de saúde e de ensino para promover a Educação Permanente entre Enfermeiros para uma situação de PCR?

\section{METODOLOGIA}

Trata-se de uma pesquisa de abordagem qualitativa, do tipo revisão da literatura exploratória. Foram buscados artigos científicos bases de dados: Pubmed, Literatura Latino-Americana e do Caribe em Ciências da Saúde (LILACS), e Biblioteca Virtual em Saúde (BVS). Os descritores pertinentes a cada base de dados e a estratégia de 
busca foram DeCS e Mesh: "Cardiopulmonary Resuscitation" e "Education, Nursing, Continuing".

Os critérios de inclusão para essa revisão foram: a) estudos que respondessem à pergunta de pesquisa; b) publicados em português, inglês ou espanhol. Excluíramse estudos a) do tipo, teses, dissertações, artigos de opinião; b) artigos sem texto completo ou duplicados;

A partir das buscas realizadas com os descritores Decs e Mesh nas bases de dados, iniciou-se um trabalho criterioso, selecionando os artigos por título, foram encontrados um total de 32 artigos. Destes, 21 foram selecionados para leitura do resumo na fase de seleção. Ao final foram selecionados 12 artigos para leitura na íntegra. Dos 12 artigos selecionados, 6 deles foram excluídos por não atender a questão em estudo, totalizando um total de 6 artigos para análise. A análise e sistematização dos dados foi realizada com base na leitura exploratória, leitura seletiva, leitura analítica e leitura interpretativa proposta por Gil (2002). Para melhor compreender esse processo de seleção, foi organizado o fluxograma Prisma Statement. 
Figura 1: Fluxograma de seleção de artigos escolhidos a parti das palavras-chave, descritores e estratégia de busca da revisão integrativa.

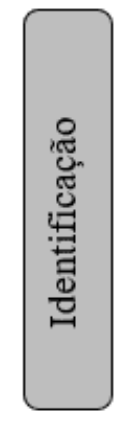

Estudos identificados por meio da pesquisa, nas bases de dados LILACS, PUBMED, BVS ( $\mathrm{n}=32)$
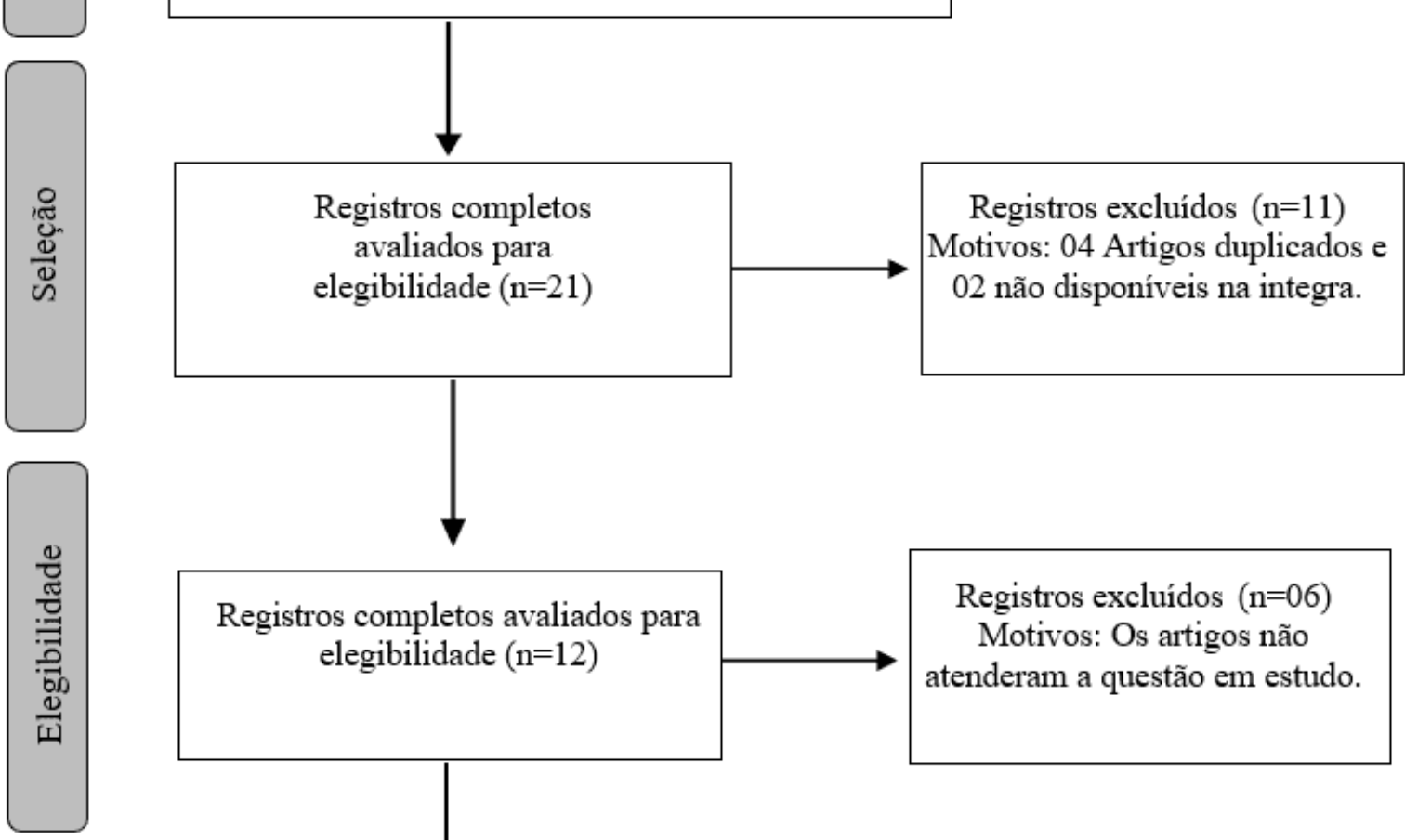

Registros excluídos $(\mathrm{n}=06)$

Motivos: Os artigos não atenderam a questão em estudo.
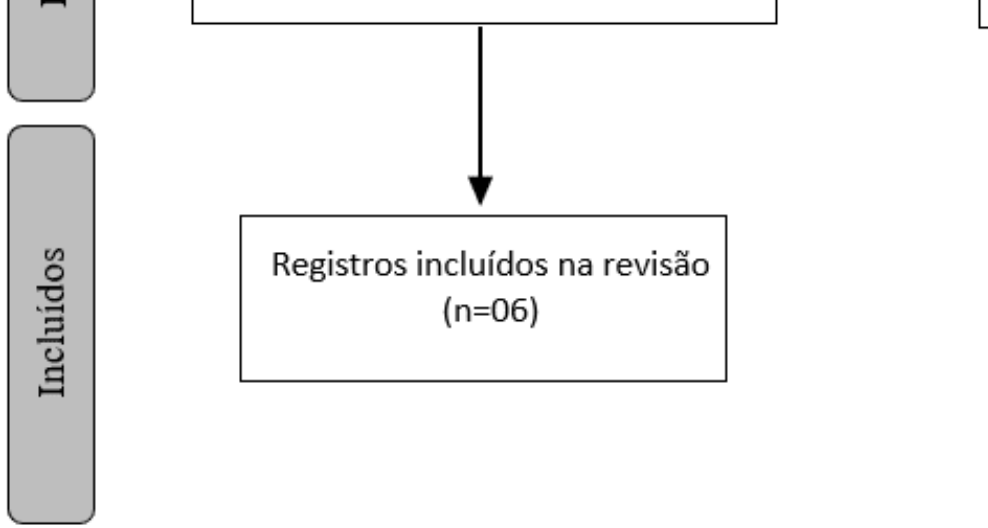

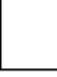

Registros incluídos na revisão $(n=06)$

Fonte: Dados da pesquisa. 


\section{RESULTADO E DISCUSSÕES}

Os artigos selecionados e analisados estão dispostos no Quadro 1. Foi possível identificar que a maior parte dos artigos foram realizados no Brasil (66,67\%), e posteriormente Estados Unidos (16,67\%) e Austrália (16,67\%). Já em relação ao ano, 16,67\% foram realizados em 2015, 33,33\% em 2016, 16,67\% em 2018 e $33,33 \%$ no ano de 2019. No que se refere as estratégias utilizadas, foi possível identificar que a mais prevalente foram treinamentos teóricos com simulação clínica e cursos online/Ambientes Virtuais de Aprendizagem (AVA).

Quadro 1: Caracterização dos artigos selecionados e analisados.

\begin{tabular}{|c|c|c|c|}
\hline Título & Autor & $\begin{array}{l}\text { Base de } \\
\text { dados }\end{array}$ & Principais achados \\
\hline $\begin{array}{l}\text { Avaliação } \\
\text { treinamento em suporte } \\
\text { básico de vida para } \\
\text { médicos e enfermeiros } \\
\text { da atenção primária }\end{array}$ & $\begin{array}{l}\text { MEIRA } \\
\text { JÚNIOR et al., } \\
2016\end{array}$ & LILACS & $\begin{array}{l}\text { O nível de conhecimentos e } \\
\text { habilidades foi insatisfatório } \\
\text { antes do curso. Após a } \\
\text { capacitação, a média de } \\
\text { acertos na avaliação } \\
\text { teórico-prática apresentou } \\
\text { aumento significativo. }\end{array}$ \\
\hline $\begin{array}{l}\text { Comparação de } \\
\text { métodos de treinamento } \\
\text { de renovação de } \\
\text { suporte básico de vida } \\
\text { online e tradicional para } \\
\text { enfermeiros } \\
\text { profissionais } \\
\text { registrados }\end{array}$ & $\begin{array}{l}\text { SERWETNYK } \\
\text { et al., } 2015\end{array}$ & PUBMED & $\begin{array}{l}\text { As descobertas indicam } \\
\text { que os métodos online para } \\
\text { renovação do Suporte } \\
\text { Básico de Vida oferecem } \\
\text { economia de tempo e } \\
\text { custo, enquanto mantêm } \\
\text { resultados positivos de } \\
\text { aprendizagem, satisfação e } \\
\text { nível de confiança dos }\end{array}$ \\
\hline
\end{tabular}




\begin{abstract}
vida em parada cardiorrespiratória: inovação para educação permanente.
\end{abstract}

Curso on-line sobre TOMAZINI et LILACS suporte avançado de al., 2018 participantes.

O curso estruturado em nove unidades de aprendizagem, foi avaliado por 16 enfermeiros especialistas, obtendo índices de alta qualidade em 15. Credenciando-o assim como um recurso valido como estratégia de educação para atendimento na RCP.

O AVA foi organizado em módulos e composto por textos elaborados a partir de pesquisa bibliográfica, links, vídeos e questões. Após a sua construção, foi avaliado como adequado para satisfazer às necessidades do públicoalvo, por oito juízes especialistas, sendo disponibilizado para acesso eletrônico.

\begin{tabular}{l|l|l|l}
$\begin{array}{l}\text { Experiência de } \\
\text { enfermeiras de }\end{array}$ & PUBMED & $\begin{array}{l}\text { Seis estações de trabalho } \\
\text { durante um tempo } \\
\text { emergência em postos } \\
\text { de trabalho de suporte }\end{array}$ \\
IRELAND ed & al., 2019 & & $\begin{array}{l}\text { dedicado em serviço. No } \\
\text { seguimento de } 6 \text { meses, a } \\
\text { básico e avançado de } \\
\text { vida adulto como uma }\end{array}$ \\
maioria dos enfermeiros \\
$(97,1 \%)$ considerou o
\end{tabular}

Disponível em: https://www.nucleodoconhecimento.com.br/saude/reanimacao- 
estratégia de apoio para

a prática clínica no

serviço de emergência. programa benéfico e 82 $(80,4 \%)$ relataram usar o conhecimento e as habilidades adquiridas com o programa em sua prática clínica.

\begin{tabular}{|c|c|c|c|}
\hline $\begin{array}{l}\text { Programa de } \\
\text { treinamento } \\
\text { teórico/prático in loco } \\
\text { para enfermagem acerca } \\
\text { das manobras básicas } \\
\text { em ressuscitação } \\
\text { cardiopulmonar. }\end{array}$ & $\begin{array}{l}\text { ASSALIN et } \\
\text { al., } 2019\end{array}$ & LILACS & $\begin{array}{l}\text { Treinamento teórico e } \\
\text { prático in loco com } \\
\text { simulação clínica de } \\
\text { Parada Cardiorrespiratória. } \\
\text { O maior desempenho foi no } \\
\text { reconhecimento da PCR, } \\
\text { assim, a intervenção } \\
\text { realizada mostrou-se } \\
\text { eficaz, já que houve } \\
\text { aumento significativo nos } \\
\text { acertos do pós-teste }\end{array}$ \\
\hline
\end{tabular}

Fonte: Dados da pesquisa.

Em relação as estratégias utilizadas para a promoção da Educação Permanente em Saúde sobre SBV e SAV em uma PCR voltada à Enfermeiros, foi possível evidenciar que todas as estratégias encontradas nos estudos tiveram resultados positivos no aprendizado (ASSALIN et al., 2019; IRELAND et al., 2019; MEIRA JÚNIOR et al., 2016; SERWETNYK et al., 2015; SILVA et al., 2016; TOMANIZI et al., 2018).

No que se refere à utilização de treinamentos teórico e práticos com simulação clínica (simulação realística ou semirealística), foi possível identificar que tal estratégia pode favorecer a melhoria do conhecimento e das habilidades em SBV entre os profissionais que trabalham na Atenção Básica, dentre eles, os profissionais Enfermeiros (MEIRA JÚNIOR et al., 2016). 
Corroborando com este achado, Ireland e colaboradores (2019) concluíram que a realização de práticas regulares e contemporâneas de manobrar de ressuscitação, forneceu aos enfermeiros de um serviço de emergência os conhecimentos necessários e atualizados. Desta forma, pode garantir a oportunidade de aprimorar as habilidades necessárias para a realização da ressuscitação cardiorrespiratória, e o desenvolvimento destas habilidades também auxiliou aos profissionais enfermeiros a ganhar confiança para posteriormente aplicar tais habilidades na sua rotina diária (IRELAND et al., 2019).

Ademais, notou-se que as intervenções teóricas e práticas realizadas in loco (ou seja, no local de trabalho) também demonstraram ser eficazes, resultando em um aumento da retenção do conhecimento. Tal fato pode ser evidenciando por meio do aumento do percentual de acertos sobre as manobras de ressuscitação cardiopulmonar nas avaliações pós-teste quando comparadas às avaliações prétestes (ASSALIN et al., 2019).

Estudo realizado em Rio Branco/AC, analisou o perfil e conhecimento teórico sobre PCR de médicos e enfermeiros de um hospital de Urgência e Emergência, e mostrou que, a maioria dos participantes $70,6 \%$, tinham um tempo de experiência menor que cinco anos e não possuíam curso de suporte básico de vida, evidenciando o baixo investimento na capacitação para adquirir conhecimentos para $o$ atendimento de PCR e RCP (FERREIRA; FERREIRA; CASSEB, 2012).

Assalin e colaboradores (2019) ressaltam a necessidade de reconhecer a importância das realizações de capacitações para os profissionais da Enfermagem em relação às manobras de SBV e SAV. Do mesmo modo, justificam que as capacitações não ocorram por diversas vezes devido à ausência de um treinamento validado e sistematizado, além das dificuldades operacionais na realização dessas capacitações (ASSALIN et al., 2019).

O estudo de Serwetnyk et al. (2015) avaliou e comparou três tipos diferentes de estratégias baseadas nos protocolos da American Heart Association, sendo elas: 
uma estratégia convencional em sala de aula; uma instrução online individualizada; e uma simulação eletrônica individualizada. Ambas as estratégias demonstraram resultados positivos, pois permitiram o desenvolvimento e aprimoramento dos conhecimentos acerca das manobras de RCP. Entretanto, em relação à sua eficácia, - método de capacitação online demonstrou resultados significativos de aprendizagem, atrelados a uma grande economia de custos e de tempo, e ainda conseguindo manter a satisfação do aluno (SERWETNYK et al., 2015).

O conhecimento e as constantes atualizações permitem que o profissional Enfermeiro seja capaz de identificar precocemente a necessidade de uma RCP, possibilitando uma resposta mais rápida na realização das manobras no paciente e consequentemente afetando de maneira positiva na sua sobrevida e alta hospitalar (SERWETNYK et al., 2015). Por isso, independentemente do método/estratégia utilizado, ressalta-se a necessidade de realizar capacitações e treinamentos que estimulem a EPS entre profissionais da Enfermagem a respeito da temática de PCR em SBV e SAV.

Além das estratégias presenciais, outra estratégia que ganhou destaque nos estudos encontrados foi a utilização de tecnologias e treinamentos não presenciais, como cursos online e Ambientes Virtuais de Aprendizagem.

Sendo considerado um recurso válido para a EPS, cursos online sobre SAV em uma PCR possuem a capacidade de integrar uma estratégia educacional inovadora juntamente com a tecnologia para promover um maior conhecimento acerca do atendimento em uma reanimação cardiopulmonar por enfermeiros (TOMAZINI et al., 2018).

Corroborando com os cursos online, o desenvolvimento de um AVA para a capacitação de profissionais em geral e Enfermeiros em um Atendimento PréHospitalar, pode ser considerado como uma ferramenta que permite a capacitação destes serviços, permitindo o subsídio de conteúdos teóricos e práticos que são 
indispensáveis para um atendimento efetivo às vítimas, garantindo uma assistência de qualidade na PCR (SILVA et al., 2016).

Nesse sentido, a realização de treinamentos e capacitações no local de serviço são um fator importante para a participação efetiva dos profissionais do serviço, pois possibilitam que o mesmo desenvolva seus conhecimentos e práticas sem a necessidade de deslocamento ou utilizar seu tempo livre para realiza-lo. Ademais, as capacitações in loco permitem que sejam agregados ao desenvolvimento das práticas, os materiais disponíveis no local, possibilitando que os profissionais sintamse mais habituados e favoreça uma EPS efetiva.

Em contrapartida, existem muitos aspectos que podem dificultar a implementação de treinamentos, dentre eles a disponibilidade de tempo, recursos e uma equipe especializada ou com vasto conhecimento sobre a temática. Nesse sentido, a utilização de estratégias não-convencionais e inovadoras como cursos online pode auxiliar na efetivação da EPS e favorecer os conteúdos necessários para uma atualização periódica dos profissionais Enfermeiros.

Assim, reafirma-se a importância da pesquisa, tendo em vista que foram identificados estudos de revisão que analisem as estratégias utilizadas na realização da EPS em SBV e SAV entre Enfermeiros.

\section{CONSIDERAÇÕES FINAIS}

No presente estudo foi possível identificar que a literatura científica aponta duas principais estratégias de desenvolvimento da EPS em relação ao atendimento a PCR em adultos por profissionais da Enfermagem, sendo elas o treinamento teórico e prático com simulação clínica e a utilização de cursos online e AVA.

Evidenciou-se muitas facilidades e limitações na efetivação da EPS em SBV e SAV entre Enfermeiros, além disso, foram identificados poucos estudos recentes sobre essa temática, o que corrobora com a necessidade de que novos estudos sejam 
realizados para auxiliar no aprimoramento das estratégias já existentes e também promover o desenvolvimento de novas estratégias.

\section{REFERÊNCIAS}

AMERICAN HEART ASSOCIATION. Destaques da American Heart Association: Atualizações das diretrizes de RCP e ACE de 2020. ECC Guidelines Heart, [s.I.], [2020]. Disponível em: https://cpr.heart.org/-/media/cpr-files/cpr-guidelinesfiles/highlights/hghlghts_2020eccguidelines_portuguese.pdf. Acesso em: 29 de Setembro de 2020.

AMERICAN HEART ASSOCIATION. Destaques da American Heart Association 2015: Atualizações das diretrizes de RCP e ACE. ECC Guidelines Heart, [s.I.], [2015]. Disponível em: <https://eccguidelines.heart.org/wpcontent/uploads/2015/10/2015-AHA-Guidelines-Highlights-Portuguese.pdf>

AMESTOY, Simone Coelho et al. Paralelo entre educação permanente em saúde e administração complexa. Revista Gaúcha de Enfermagem, v. 31, n. 2, p. 383-387, 2010.

ASSALIN, A. C. et al. Programa de Treinamento Teórico/Prático In Loco para Enfermagem Acerca das Manobras Básicas em Ressuscitação Cardiopulmonar. Rev. Fund. Care Online, v. 11, n. esp., p. 495-501, 2019.

BRASIL. Ministério da Saúde. Secretaria de Gestão do Trabalho e da Educação na Saúde. Departamento de Gestão da Educação na Saúde. A educação permanente entra na roda: polos de educação permanente em saúde: conceitos e caminhos a percorrer. $2^{\underline{a}}$ ed. Brasília: Ministério da Saúde; 2005.

DIAZ, Flávia Batista Barbosa de Sá et al. Conhecimento dos enfermeiros sobre o novo protocolo de ressuscitação cardiopulmonar. Rev. enferm. Cent.-Oeste Min, p. 1-8, 2017. 
FERREIRA, José Vitor Benevides; FERREIRA, Silvana Margarida Benevides; CASSEB, Giovanni Bady. Perfil e conhecimento teórico de médicos e enfermeiros em parada cardiorrespiratória, município de Rio Branco, AC. Rev Bras Cardiol, v. 25, n. 6, p. 464-70, 2012.

ARANDA-GARCÍA, Silvia; HERRERA-PEDROVIEJO, Ernesto; ABELAIRASGÓMEZ, Cristian. Aprendizagem de Suporte Básico de Vida em alunos de graduação em Ciências do Esporte: Eficácia de 150 minutos de treinamento e retenção após oito meses. Jornal internacional de pesquisa ambiental e saúde pública , v. 16, n. 23, pág. 4771, 2019.

GIL, A. C. Como elaborar projetos de pesquisa. 4ª ed. São Paulo: Atlas, 2002. p. 5985.

PALHARES GUIMARÃES, Eliane Marina; HAUEISEN MARTIN, Sandra; PAOLINELLI RABELO, Flávia Cristina. EDUCACIÓN PERMANENTE EN SALUD: Reflexiones y desafíos. Ciencia y enfermeria, v. 16, n. 2, p. 25-33, 2010.

IRLANDA, Sharyn et al. Experiência de enfermeiras de emergência em postos de trabalho de suporte básico e avançado de vida adulto como estratégia de apoio à prática clínica em pronto-socorro. Atendimento de emergência na Australásia, v. 23, n. 2, pág. 77-83, 2020.

KARDONG-EDGREN, Suzan E. et al. Comparison of two instructional modalities for nursing student CPR skill acquisition. Resuscitation, v. 81, n. 8, p. 1019-1024, 2010.

MEIRA JÚNIOR, L. E. et al. Avaliação de treinamento em suporte básico de vida para médicos e enfermeiros da atenção primária. Rev. Bras. Med. Fam. Comunidade, v. 11, n. 38, p. 1-10, 2016.

MERHY, Emerson Elias; FEUERWERKER, Laura Camargo Macruz; CECCIM, Ricardo Burg. Educación permanente en salud: una estrategia para intervenir en la micropolítica del trabajo en salud. Salud colectiva, v. 2, p. 147-160, 2006. 
SERWETNYK, Tara M. et al. Comparison of online and traditional basic life support renewal training methods for registered professional nurses. Journal for nurses in professional development, v. 31, n. 6, p. E1-E10, 2015.

SILVA, Anazilda Carvalho da et al. Development of a virtual learning environment for cardiorespiratory arrest training. Revista da Escola de Enfermagem da USP, v. 50, n. 6, p. 990-997, 2016.

TOMAZINI, Edenir Aparecida Sartorelli et al. Curso on-line sobre suporte avançado de vida em parada cardiorrespiratória: inovação para a educação permanente. Rev. Rene, v. 19, p. e32444, 2018.

Enviado: Maio, 2021.

Aprovado: Junho, 2021. 